\title{
Analysis of alternative actions for import substitution policy implementation in machine engineering complex
}

\author{
Sergey Chevychelov ${ }^{1, *}$, Igor Kotov ${ }^{1}$, and Sergey Klevtsov ${ }^{2}$ \\ ${ }^{1}$ Southwest State University, 305040 Kursk, Russia \\ ${ }^{2}$ Kursk Institute of the Cooperation, 305000 Kursk, Russia
}

\begin{abstract}
This paper discusses the considerations for production modernization, replacement of imported spare parts manufactured in-house and redistribution of items manufactured spare parts between managed societies, with a goal to improve the quality and reliability of products, to reduce its cost, and work. Noted that the process of acquiring new foreign equipment and modern materials are complicated. There are examples of restrictive measures of the sanctions impact on industrial products and the dynamics of dependency on imports of industrial products. We used analytic and statistical research methods. Authors conducted a comparative analysis of the engineering assets of «Metalloinvest» holding that showed that all businesses have an impressive fleet of metal-working equipment on all groups of machines on the basis of an analysis of the needs for them to transport spare parts.
\end{abstract}

\section{Introduction}

The innovation potential of a machine-building complex is the main competitive advantage of the developed countries, which focused on an integrated approach to the use of tools to support innovation activities of enterprises and enhance public-private partnerships involving research and educational organizations, enterprises and institutions of development.

Production in industrial sectors, in particular of machine-building industry, is carried out using imported equipment from leading manufacturers in the field of metalworking and equipment, and using the equipment procured within the country[1-4].

Among foreign scientists analysis the policy of import substitution in a machine-building complex such as W. Hongyuan, Z. Xunjiang, D. Weifeng [5], M. Jahani, A. Farzanegan, M. Noaparast [7], F. Elskamp, H. KruggelEmden [8], G. Wang, X. Tong[9].

\section{Results and discussion}

However, in connection with the recent complex geopolitical and economic environment and the introduction of a series of sanctions in industrial complex (table 1) is complicated by the acquisition of new foreign equipment and modern materials.

Many countries, not only imports industrial equipment, but also manufactured goods, in table 2 you can see that many countries depend both on imported industrial machinery and products.

Table 1. Examples of restrictive measures of the sanctions impact on the industrial products*.

\begin{tabular}{|c|c|}
\hline $\begin{array}{c}\text { An example of the impact of } \\
\text { sanctions }\end{array}$ & $\begin{array}{c}\text { The country, which } \\
\text { sent the impact of } \\
\text { sanctions }\end{array}$ \\
\hline $\begin{array}{c}\text { embargo on dual-use goods and } \\
\text { technologies intended for } \\
\text { military use or for the military } \\
\text { end user }\end{array}$ & Russia \\
\hline a ban on the export of certain \\
equipment
\end{tabular}

*http://www.bscn.nl/sanctions-consulting/sanctions-list-countries

Table 2. Dynamics of dependence on imports for industrial production (\% of imported industrial products).

\begin{tabular}{|c|c|c|c|c|c|}
\hline Country & $\mathbf{2 0 0 9}$ & $\mathbf{2 0 1 0}$ & $\mathbf{2 0 1 1}$ & $\mathbf{2 0 1 2}$ & $\mathbf{2 0 1 4}$ \\
\hline Ukraine & 52,2 & 53 & 53,2 & 56,3 & 56,8 \\
\hline Belarus & 45,1 & 47,3 & 41,7 & 46,3 & 47 \\
\hline Russia & 76,5 & 74,5 & 74,9 & 83,1 & 82,2 \\
\hline
\end{tabular}

Therefore, in modern terms, one of the main problems is the problem of import substitution in industry at the national level [10-13].

To date, the process of import substitution is relevant in view of the unstable political and economic situation in the world. On the basis of modern high-quality technologies you should produce more important modern and innovative products. It is advisable to organize their

\footnotetext{
*Corresponding authors: tschsa@yandex.ru
} 
own production, repairs and servicing, to use of highly qualified specialists, to conclude a cooperation agreement with Russian companies.

The Ministry of trade and industry of the Russian Federation implements state import substitution programme at the national level in the industrial sector, in particular, on the critically important areas. Critically important position, mainly those on the world market are either monopolies or oligopolies, i.e. access is closed or restricted, and the level of dependency on Russian industry from such positions above the critical level.

Financial support measures, such as subsidies to complex investment projects, working capital and the mechanism of the Fund for the development of industry, also focused on import substitution projects. In this sense, import substitution is intended to offset shrinking domestic demand, to ensure technological independence, to ramp up their competence to world market prices[14].

However, import substitution in engineering, from the point of view of some economists, it would take about five to seven years, in the light of the development of scientific, technological and productive capacities. To reach the target level of substitution on the most soughtafter items of equipment need additional funding of about 12-15 billion rubles from budget in 2015-2020th, which will be used to develop new technologies and create serial productions.

In the process of import substitution and export products technological level of industry are increased, as well as her willingness to work successfully for long-term development vector[15-17]. The only way to cope with an artificial restriction on the technological level and competitiveness of our products is the implementation of a program to support investment machinery, engineering, contract life cycle. The Government is now considering the possibility to launch a program of support for the development of the production of the means of production, waiting for the next budget cycle, in the framework of anti-crisis plan-2016. On the assessment of the Ministry of industry and trade, in the year 2016 it will need about 20 billion rubles. Another strategic direction is the new point of growth, based on prospective developments that will be converted into new, large-scale global markets in term of 15-20 years [18].

During the project implementation «Import substitution Centre» in close partnership with Russian Engineering Union orientation occurs primarily on the formation of a new industrial paradigm in Russia. Development of industrial infrastructure and establishes a basic funds[19-20].

The key question is the basic funds of enterprises of the machine-building complex. Manufacture of machine tools is an industry that generates funds, which provides technological equipment all strategic spheres of machinebuilding and the military-industrial complexes[21-23].

Thus, when evaluating the potential of implementing the strategy of import substitution in the framework of a specific industrial sector there is a need to analyse the potential of this complex. The machine-building complex is able to play a vital role in the economy of the region with innovative renewal conditions of radical modernization of facilities engineering, active policies of import substitution, bringing effective investors and strategic partners.

Comparative analysis of engineering assets of «Metalloinvest» holding showed that all businesses have an impressive fleet of metal-working equipment, in relation to all groups of machines.

Let us analyze the needs for imported spare parts for the surveyed enterprises. On request, the management organization for information on requirements for imported spare parts received lists for the year 2016. The results of the analysis checklists are presented in table 3 .

Thus, it is possible to recommend a draw in 2016 year engineering and consulting company for the purpose of:

— detailed analysis in managed organization nomenclature import spare parts, to determine whether the development of analogs of own production, in view of the series of products and terms of operation of the equipment;

- development of design documentation for imported spare parts to be procured;

- development of technological documentation for production of spare parts import analogues;

- plot design for manufacture analogues of spare parts are imported;

- development of feasibility study of the construction site for the manufacture of spare parts import analogues.

Table 3. Analysis of the need for import of spare parts.

\begin{tabular}{|l|r|r|r|r|}
\hline \multirow{2}{*}{$\begin{array}{c}\text { Managed } \\
\text { organization }\end{array}$} & \multicolumn{4}{|c|}{ Positions on the list, units } \\
\cline { 2 - 5 } critical & $\begin{array}{l}\text { moderately } \\
\text { critical }\end{array}$ & $\begin{array}{l}\text { not } \\
\text { critical }\end{array}$ & total \\
\hline JSC «OEMK» & 186 & 40 & 0 & 226 \\
\hline $\begin{array}{l}\text { Jsc } \\
\text { «Mikhailovsky } \\
\text { Gok» }\end{array}$ & 119 & 92 & 53 & 264 \\
\hline $\begin{array}{l}\text { JSC «Lebedinsky } \\
\text { Gok» }\end{array}$ & 1154 & 1149 & 12 & 2315 \\
\hline JSC «Ural steel» & 107 & 43 & 6 & 156 \\
\hline \multicolumn{1}{|c|}{ TOTAL } & 1566 & 1324 & 71 & 2961 \\
\hline
\end{tabular}

Authors revealed that preparations for the majority of products are forgings. It was therefore considered the possibility of manufacturing forgings forces managed entities. In parallel, the possibility of replacement purchase its own production of forgings of blanks for already mastered an item.

Cost structure for each of the managed entities is not uniform, each enterprise is allocated their own factors with the greatest influence on the final cost of production and, consequently, the prices of spare parts.

For leveling influence the negative features of the accounting and pricing on each managed organizations in the production of spare parts it is advisable to proceed with the development and approval of unified rules of pricing machine processing managed entities.

Cost reduction redistribution on managed entities download growth workshop at $10 \%$.

As a result of increasing loading machine shops of managed organization at $10 \%$ may get cost redistribution at $6 \%$ due to the action: 
- production scale (increasing the volume of production decreases the magnitude of fixed costs per unit of output spare parts; the result is a decrease in unit cost with the growth of volumes of manufacture);

- synergies between several units of the «Metalloinvest» holding.

We have a comprehensive analysis of alternatives to improve the utilization of engineering assets and their strategic development.

Development of new nomenclature for spare parts purchased from third-party vendors, for the needs of managed societies, divided into 5 options:

Alternative 1: manufacturing of products subject to harness existing unused machinery assets when possible transfer of equipment for 24 hours and increased staffing levels.

Alternative 2: possibility to manufacture products in accordance with the list provided (refinement) of the design documentation (new nomenclature of spare parts of our own production).

Alternative 3: Mastering the products on the list, subject to the acquisition of workpieces or parts, manufacture of which is impossible in conditions of managed organization.

Alternative 4: manufacturing of products subject to the acquisition of equipment and increase in staff (procurement of new equipment).

Alternative 5: castings, which do not require further machining.

Manufacturing of products subject to change operation mode shifts existing engineering assets, with the necessary resources (table 4).

For the implementation phase activities need to be developed for the manufacture of tooling for the year 2016 followed by manufacturing products in quantities 21 names (3122 places) a year weighing 1004.94 tons to the amount of 58388.6 thousand rubles.

Table 4. Alternatives for improving the efficiency of engineering assets when implementing the concept of import substitution.

\begin{tabular}{|c|c|c|c|c|c|c|c|c|c|c|c|}
\hline \multicolumn{12}{|c|}{ Alternative 1} \\
\hline \multirow{4}{*}{$\begin{array}{c}\text { Managed } \\
\text { organizations }\end{array}$} & \multicolumn{2}{|c|}{$\begin{array}{c}\text { Position claimed } \\
\text { managed } \\
\text { organizations } \\
\end{array}$} & \multicolumn{8}{|c|}{ Position, planned to manufacture in managed organizations } & $\begin{array}{l}\text { The necessary } \\
\text { resources }\end{array}$ \\
\hline & \multirow{3}{*}{ 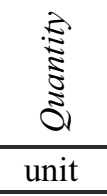 } & \multirow{3}{*}{ 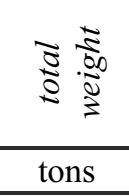 } & \multirow{3}{*}{ 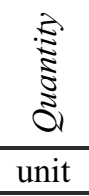 } & \multirow{2}{*}{ 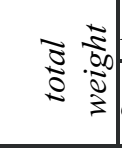 } & \multicolumn{6}{|c|}{ Positions on the levels of criticality } & \multirow{2}{*}{$\begin{array}{l}\text { the number } \\
\text { workers }\end{array}$} \\
\hline & & & & & \multicolumn{2}{|c|}{ critical } & \multicolumn{2}{|c|}{$\begin{array}{l}\text { Moderately } \\
\text { ritical }\end{array}$} & \multicolumn{2}{|c|}{ not critical } & \\
\hline & & & & tons & unit & $\%$ & unit & $\%$ & unit & $\%$ & person \\
\hline JSC «OEMK» & 39 & 7,43 & 32 & 6,06 & 28 & 87,5 & 4 & 12,5 & 0 & 0,0 & 1 \\
\hline \begin{tabular}{|l} 
Jsc \\
«Mikhailovsky \\
Gok»
\end{tabular} & 18 & 243,3 & 21 & 220,6 & 6 & 28,6 & 10 & 47,6 & 5 & 23,8 & 7 \\
\hline $\begin{array}{l}\text { JSC «Lebedinsky } \\
\text { Gok» }\end{array}$ & 39 & 494,6 & 43 & 518,7 & 35 & 81,4 & 8 & 18,6 & 0 & 0,0 & 17 \\
\hline JSC «Ural steel» & 1 & 7,7 & 1 & 7,7 & 1 & 100 & 0 & 0,0 & 0 & 0,0 & 1 \\
\hline TOTAL & 97 & 753,1 & 97 & 753,1 & 70 & 72,2 & 22 & 22,7 & 5 & 5,1 & 26 \\
\hline \multicolumn{12}{|c|}{ Alternative 2 } \\
\hline \multirow{3}{*}{$\begin{array}{l}\text { Managed } \\
\text { organizations }\end{array}$} & & \multicolumn{8}{|c|}{ Positions on the levels of criticality } & \multirow{2}{*}{\multicolumn{2}{|c|}{ Necessary resources }} \\
\hline & 离 & \multicolumn{2}{|l|}{ critical } & \multicolumn{2}{|c|}{ moderately critical } & \multicolumn{4}{|c|}{ not critical } & & \\
\hline & units & units & $\%$ & units & $\%$ & & units & & $\%$ & & person/day \\
\hline JSC «OEMK» & 53 & 33 & 62,3 & 9 & 17,0 & & 11 & & 20,8 & & 212 \\
\hline \begin{tabular}{|l|} 
Jsc \\
«Mikhailovsky \\
Gok» \\
\end{tabular} & 21 & 4 & 19,0 & 14 & 66,7 & & 3 & & 14,3 & & 84 \\
\hline $\begin{array}{l}\text { JSC «Lebedinsky } \\
\text { Gok» }\end{array}$ & 107 & 102 & 95,3 & 4 & 3,7 & & 1 & & 0,9 & & 428 \\
\hline JSC «Ural steel» & 0 & 0 & 0 & 0 & 0 & & 0 & & 0 & & 0 \\
\hline TOTAL & 181 & 139 & 76,8 & 27 & 14,9 & & 15 & & 8,3 & & 724 \\
\hline & & & & & Alternati & ive 3 & & & & & \\
\hline $\begin{array}{c}\text { Managed } \\
\text { organizations }\end{array}$ & $\begin{array}{l}\text { Posit } \\
\text { admi }\end{array}$ & $\begin{array}{l}\text { ns, the } \\
\text { stering }\end{array}$ & & sitions pl & $\begin{array}{r}\text { anned to } 1 \\
\text { orga }\end{array}$ & $\begin{array}{l}\text { manuf } \\
\text { anizati }\end{array}$ & $\begin{array}{l}\text { facture i } \\
\text { ions }\end{array}$ & $\mathrm{n}$ a man & naged & $\mathrm{Nec}$ & cessary resources \\
\hline
\end{tabular}




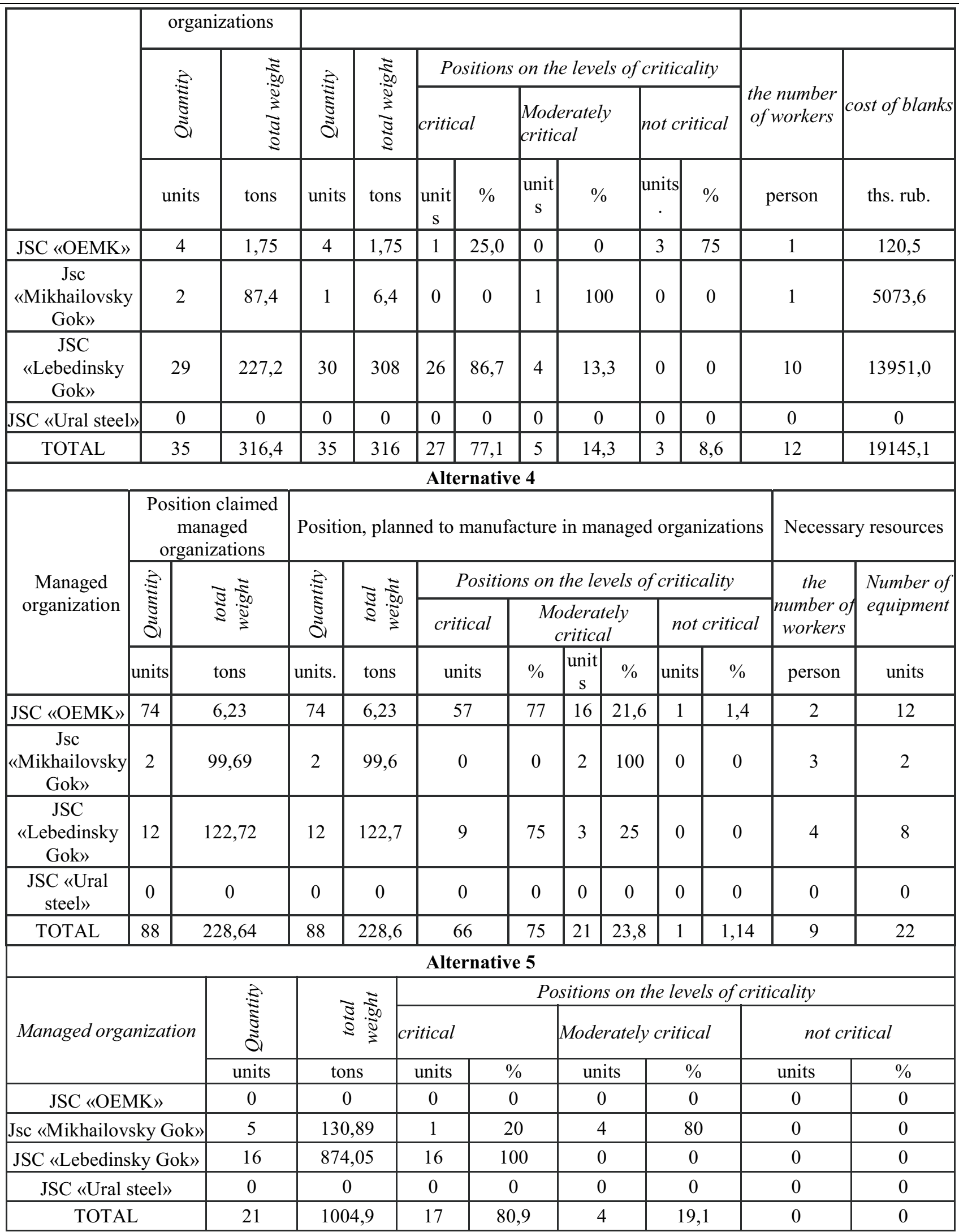

We conducted a comparative analysis of the proposed alternatives based on several criteria: 1) financial costs, 2) time lag, 3) the efficiency, 4) product quality, 5) the level of closing critical positions. On the basis of a mark estimation according to the criteria proposed alternatives held the ranking for each of them. Study a fragment is shown in table 5.

However, alternative embodiments of the manufacturing process are not only single phases but interrelated steps that implement the manufacturing process (table 6).
Thus, the level of "close" critical positions in import substitution and the sum of ranks, you can choose the following combinations:

A 2- A 1, A3- A 2- A 5- A 4- A 1, A 3- A 2- A 5- A 1, A 3-A 2-A 5. 
Table 5. Comparative analysis of options for implementing enhanced.

\begin{tabular}{|c|c|c|c|c|c|c|}
\hline $\begin{array}{c}\text { Alter } \\
\text { native } \\
\text { s }\end{array}$ & \multicolumn{6}{|c|}{ Criterias } \\
\cline { 2 - 7 } & $\begin{array}{c}\text { Financid } \\
\text { expenses }\end{array}$ & $\begin{array}{c}\text { Time } \\
\text { lag }\end{array}$ & $\begin{array}{c}\text { Efficie } \\
\text { ncy }\end{array}$ & $\begin{array}{c}\text { Quality } \\
\text { of } \\
\text { produc } \\
\text { ts }\end{array}$ & $\begin{array}{c}\text { The level } \\
\text { of "close" } \\
\text { critical } \\
\text { positions }\end{array}$ & Sum \\
\hline A1 & 1 & 1 & 2 & 5 & 3 & 12 \\
\hline A2 & 2 & 5 & 1 & 3 & 5 & 16 \\
\hline A3 & 3 & 3 & 3 & 4 & 2 & 15 \\
\hline A4 & 5 & 4 & 5 & 1 & 4 & 15 \\
\hline A5 & 4 & 2 & 4 & 2 & 1 & 13 \\
\hline $\begin{array}{l}\text { Chara } \\
\text { cterist } \\
\text { ics }\end{array}$ & $\begin{array}{c}5 \\
\text { the } \\
\text { most } \\
\text { expen } \\
\text { sive }\end{array}$ & $\begin{array}{c}5 \\
\text { the } \\
\text { lon } \\
\text { gest }\end{array}$ & $\begin{array}{c}5 \\
\text { the } \\
\text { lowe } \\
\text { st }\end{array}$ & $\begin{array}{c}5 \\
\text { the } \\
\text { lowe } \\
\text { st }\end{array}$ & $\begin{array}{c}5 \\
\text { the } \\
\text { worst }\end{array}$ & \\
\hline
\end{tabular}

Table 6. Analysis of Alternatives for Activities on Import Substitution.

\begin{tabular}{|l|l|l|}
\hline $\begin{array}{l}\text { Possible of } \\
\text { combinations for the } \\
\text { alternatives for } \\
\text { implementation of } \\
\text { measures for import } \\
\text { substitution }\end{array}$ & $\begin{array}{l}\text { The } \\
\text { sum } \\
\text { of } \\
\text { ranks }\end{array}$ & $\begin{array}{l}\text { The abbreviation } \\
\text { "critical" level of } \\
\text { production (due to } \\
\text { import } \\
\text { substitution) * }\end{array}$ \\
\hline $\begin{array}{l}\text { A3- A 2- A 5- A 4- A } \\
\text { 1 }\end{array}$ & 71 & 181 \\
\hline A 3- A 2- A 5- A 1 & 56 & 181 \\
\hline A 3- A 2- A 5 & 44 & 181 \\
\hline A 2 & 16 & 181 \\
\hline A 2- A 1 & 28 & 181 \\
\hline A 3- A 4- A 1 & 42 & 97 \\
\hline A 3- A 4 & 30 & 74 \\
\hline A 2- A 1 & 28 & 181 \\
\hline A 2- A 5 & 29 & 181 \\
\hline A 4- A 1 & 27 & 97 \\
\hline
\end{tabular}

* Index is defined as the maximum possible among the series on the basis of Table 5

The economic effect of the development of the manufacture of spare parts of managed organization, purchased from third party suppliers is presented separately for each alternative.

Table 7. Analysis of The Development of New Nomenclature of Spare Parts in Stages.

\begin{tabular}{|l|l|l|}
\hline \multirow{2}{*}{ Alternatives } & \multicolumn{2}{|c|}{$\begin{array}{c}\text { The number of "closed" } \\
\text { critical positions }\end{array}$} \\
\cline { 2 - 3 } & units & tons \\
\hline A1 & 97 & 753,11 \\
\hline A2 & 181 & - \\
\hline A3 & 35 & 316,4 \\
\hline A4 & 74 & 6,23 \\
\hline A5 & 21 & 1004,94 \\
\hline
\end{tabular}

\section{Conclusion}

The first alternative (97 items) expected annual positive economic effect in the amount of 27719.56 thousand rubles total for all managed organization, including JSC «Lebedinsky Gok»-12755.69 thousand rubles; by JSC «Mikhailovsky Gok» -12808.09 thousand rubles; on JSC «Ural steel» - 365.87 thousand rubles; at OEMK is 1789.92 thousand rubles.

When implementing a third alternative (35 items) expected annual positive economic effect in the amount of 12348.5 thousand rubles, including OEMK-262.02 thousand rubles; by JSC «Lebedinsky Gok»-6312.3 thousand rubles; by JSC «Mikhailovsky Gok» - 5774.1 thousand rubles.

When the fifth alternative (21 position) annual positive economic effect will be 30502.12 thousand rubles on all managed organization, including JSC «Lebedinsky Gok»-9449.16 thousand rubles; by JSC «Mikhailovsky Gok»-21052.96 thousand rubles.

The economic effect is the sum of the amounts of profit and a conditional cost savings in the production of additional amounts of nomenclature and spare parts.

Thus, the machine-building complex is a priority industry innovation policies of import substitution. Developing innovations in machine-building complex of developed countries should be geared to modernization and implementation of technological innovation in the strategic management of the economy.

\section{References}

[1] A.V. Maslennikov, S.A. Chevychelov, M.S. Merzhoeva, M.S. Gatiev, V.V. Sidorova, Russian Engineering Research, 34(11), 722 (2014)

[2] A.V. Maslennikov, S.A. Chevychelov, I.G. Golubev, Russian Engineering Research, 33(5), 295 (2013)

[3] S.G. Emelyanov, S.A. Chevychelov, P.P. Chistyakov, Applied Mechanics and Materials, 698, 546 (2015)

[4] M.S. Razumov, A.N. Grechukhin, A.O. Gladyshkin, Proceedings of the Institution of Mechanical Engineers, Part C: Journal of Mechanical Engineering Science, 230(18), 3298 (2016)

[5] W. Hongyuan, Z. Xunjiang, D. Weifeng, Measurement, 69, 126 (2015)

[6] L. Little, M. Becker, J. Wiese, A.N. Mainza, Minerals Engineering (2015)

[7] M. Jahani, A. Farzanegan, M. Noaparast, Powder Technology, 283, 32 (2015)

[8] F. Elskamp, H. Kruggel-Emden, Advanced Powder Technology, 26(3), 679 (2015)

[9] G. Wang, X. Tong, Mining Science and Technology (China), 21(3), 451 (2011)

[10]L.I. Aimin, L.V. Ruiling, L.I.U. Chusheng, Journal of China University of Mining and Technology, 18(2), 300 (2008)

[11] T. Dyr, P. Wodzinski, Physicochemical Problems of Mineral Processing, 35, 147 (2002) 
[12]M. Maleki-Moghaddam, M. Yahyaei, S. Banisi, Minerals Engineering, 46-47, 157 (2013)

[13]B. Axelrod, TRIZ Future 2005. Graz, Austria, University of Leoben, November, 325 (2005)

[14]B. Axelrod, ETRIA Conference, November, 131 (2007).

[15] A.I. Barbot'ko, A.V. Maslennikov, M.S. Razumov, Russian Engineering Research, 31(12), 1253 (2011)

[16] M.S. Razumov, A.I. Pykhtin, A.V. Maslennikov, Russian Engineering Research, 32(9-10), 681 (2012)

[17]A.I. Barbot'ko, M.S. Razumov, A.I. Pykhtin, P.A. Ponkratov, Russian Engineering Research, 35(5), 344 (2015)

[18] Yu. Vertakova, M. Klevtsova, T. Babich, Economical chasopis-XXI, 157(3-4), 4 (2016)

[19] Y. Vertakova, M. Klevtsova, S. Klevtsov, Proceedings of the 26th International Business
Information Management Association Conference Innovation Management and Sustainable Economic Competitive Advantage: From Regional Development to Global Growth, IBIMA 2015 26, Innovation Management and Sustainable Economic Competitive Advantage: From Regional Development to Global Growth, 3230 (2015)

[20] Y. Vertakova, Y. Polozhentseva, M. Klevtsova, Procedia Economics and Finance, 24, 750 (2015)

[21]R. Nania, D. Regazzoni, Elsevier, Engineering Procedia, 665 (2011)

[22]P. Lepšík, M. Petr, O. Novak, Modern Methods of Construction Design. Proceedings of ICMD, IV, 459 (2013)

[23] D. Russo, T. Montecchi, D. Regazzoni, Proceedings of IDMMEVirtualConcept, May, 1 (2010) 